\title{
Current Account Deficit Sustainability: a Panel Approach
}

\author{
Ahmad Zubaidi Baharumshah \\ Universiti Putra Malaysia \\ Evan Lau \\ Universiti Malaysia Sarawak \\ Stilianos Fountas \\ University of Macedonia
}

\begin{abstract}
In this paper we attempt to examine the issue of sustainability of current account imbalances in eight East Asia countries using the latest developments in nonstationary panel data analysis. The methods of nonstationary time series panels provide a much more promising explanation than would an analysis based on pure time series or cross section data. The empirical results clearly indicate that the current account imbalances were not on the long-run steady state in the pre-crisis era (1970-1997). This leads to the conclusion that the current accounts of Asia-8 during this period were unstable and did not move towards external account equilibrium. However, strong comovements between exports and imports are found in the extended sample period that includes the post-crisis period (1970-2000). This result implies that large currency depreciations and the economic recovery have brought the Asia8 economies back on a sustainable path. Thus, current account imbalances may be used as an indicator (or warning signal) in predicting future crises.
\end{abstract}

- JEL Classifications: F30, F32

- Key words: Current account deficits, Sustainability, Panel cointegration, Asian economies

\footnotetext{
*Corresponding address: Ahmad Zubaidi Baharumshah, Department of Economics, Faculty of Economics and Management, Universiti Putra Malaysia, 43400 Serdand Selangor, Malaysia, Tel: $+603-$ 948601(ext. 1621), Fax: +603-9486188, E-mail: zubaidi@econ.upm.edu.my. Evan Lau, Faculty of Economics and Business, Universiti Malaysia Sarawak, 94300 Kota Samarahan, Sarawak, Malaysia. Stilianos Fountas, Department of Economics, University of Macedonia, 156 Egnatia St., Thessaloniki 540 06, Greece, Tel: +30-2310-891774, Fax:+30-2310-891777, E-mail: sfountas@uom.gr (C2005-Center for International Economics, Sejong Institution, All Rights Reserved.
} 


\section{Introduction}

One of the most discussed issues in the field of international finance in recent times has been the sustainability of a country's current account disequilibrium. The discussion of this subject has focused mainly on the question of whether the US current account deficit that is forecast to reach $\$ 550$ billion or 5 per cent of GDP in 2003 (Schwartz, 2003) is sustainable, an issue of significant importance for policymakers and academic economists alike (Holman, 2001; Mann, 2002). Standard textbook analysis indicates that the current account is a mirror image of changes in national net indebtedness. The general wisdom has been that current account imbalances are to be expected and balanced trade is unlikely to be an optimal outcome for an economy. As pointed out by $\mathrm{Wu}$ (2000), temporary current account deficits reflect reallocation of capital to the country where capital is most productive and thus may not create problems for the economy. However, permanent or persistent deficits can have serious effects. First, they might increase domestic interest rates to attract foreign capital, and second, the accumulation of external debt due to persistent deficits will imply increasing interest payments, imposing an excess burden to future generations. In addition, the persistence of large current account deficits raises the issue of whether these deficits are sustainable. Indeed, the financial crises of the 1990s (including those of the East Asia) demonstrate that a large current account deficit may trigger a sharp hike in interest rates, a rapid depreciation of exchange rates and hence may disrupt the performance of the domestic economy. The Mexican crisis of 1994-95 was similarly preceded by a very large current account deficit.

A sustainable current account represents a stable state in which the deficit generates no forces of its own to change its trajectory. On the other hand, an unsustainable current account disequilibrium triggers by its own forces an interest rate hike, a large depreciation, or some other sudden domestic or global economic disruption (Mann, 2002).

Measuring current account sustainability has been a highly contentious issue (Holman, 2001, Mann, 2002). Developments in time series techniques, notably tests for stationarity, allow for econometric testing of the sustainability hypothesis. The issue of current account stationarity is important for at least two reasons. First, a stationary current account is consistent with the sustainability of the current account, and hence is an indication that a country will not default on its international debt. Second, the stationarity of current account agrees with the 
implication of the modern intertemporal approach to the current account and thus supports its validity (Obstfeld and Rogoff, 1996, p. 90) ${ }^{1}$. However, the bulk of the empirical evidence based on classical unit root tests suggests that the current account is nonstationary in its level (see for example, Otto, 1992; Shibata and Shintani, 1998) ${ }^{2}$. To settle this important issue, a number of authors (for example, Husted, 1992 and $\mathrm{Wu}, 2000$ ) have sought to prove the mean reversion in the current account by examining the cointegration properties between exports and imports. The claim that the current account is sustainable if exports and imports are cointegrated with the cointegrating vector being $(1,-1)$, is, by now, a widely accepted theory. To examine the long-run relationship between the two variables in this framework, the popular residual-based cointegration method of Engle and Granger (1987) and the method of Johansen and Juselius (1990) have been applied by several authors (Wickens and Uctum, 1993; Cashin and McDermott, 1998; Fountas and $\mathrm{Wu}, 1999$; and Irandoust and Boo Sjoo, 2000). One notable exception is Wu et al. (2001); they utilize the panel cointegration tests, i.e., not tests based on pure time series data, to investigate the long-run relationship between exports and imports ${ }^{3}$.

The testing of the sustainability of the current account deficit has generally relied on data from the industrialized countries, notably the US. Nevertheless, the debt crisis of the 1980s, the Latin American crisis and the more recent Asian financial crises have led several authors to assess the behavior of the current accounts of these developing countries. Milesi-Ferretti and Razin (1996) look at a group of countries in East Asia and Latin America; Yan (1999) considers East Asia; Apergis et al. (2000) looks at Greece and Adedeji (2001) considers Nigeria. However, all of these papers share a common feature. The modeling strategy has generally relied on pure time series data and empirical testing has been limited until recently by data constraints. Pooling the data from a group of countries can compensate for the

\footnotetext{
The modern intertemporal approach to the current account determination combines the assumptions of perfect capital mobility and consumption-smoothing behavior to predict that the current account acts as a buffer to smooth the consumption in the event of shocks. This implies that the current account will typically behave like a stationary variable.
}

${ }^{2}$ Researchers using single equation tests for nonstationarity of the current account have not been able to reject the null hypothesis of unit root behaviour, probably due to lack of power of these tests in small samples. It is well known that conventional unit root tests have low power when the root is close to unity. Shiller and Perron (1985) find that the power of the ADF test is low with short data spans.

${ }^{3} \mathrm{Wu}$ et al. (2001) used the panel cointegration method to test the sustainability of current account for the G7 countries. The results are in line with a sustainable current account. 
lack of time series observations.

This paper attempts to provide an in-depth analysis on the sustainability of current account imbalances for eight major East Asia (hereafter Asia-8) economies. To research this problem, we draw on the recent development of the panel data unit root test technique of Im et al. (1997) and the multivariate residual panel cointegration test pioneered by Pedroni $(1997,1999)$. In addition, we adopt the dynamic OLS model (DOLS) proposed by Kao and Chiang (2000) to further investigate the long-run relationship among the coefficients of the model. The nonstationary panel data ${ }^{4}$ approach offers a more promising explanation in the empirical world given the well-known power deficiencies which plague pure timeseries based tests for unit roots and cointegration (Banerjee, 1999). This research extends the Wu et al. (2001) study on the G7 to the Asia-8 experiences.

This study is interesting for the following reasons. First, this paper, unlike the others, is the first attempt that examined the issue of sustainability in current account imbalances using a cluster of Asia- 8 countries. The eight countries in the panel are Singapore, Taiwan and South Korea of the Newly Industrialized Countries (NICs), Malaysia, Thailand, Indonesia, and Philippines of the Newly Industrialized Economies (NIEs) and Japan, as an industrialized economy. Moreover, in the aftermath of the Asian financial crisis, the countries in the panel can be broadly divided into the crisis-affected economies (Indonesia, Malaysia, the Philippines, South Korea, and Thailand) and the non-affected economies (Japan, Taiwan, and Singapore). The purpose, therefore, is to capture the cross-sectional information of all these economies in one panel. Second, the modeling strategy adopted in this study differs from that of most of the earlier studies in that we extend the analysis to include data from the recent Asian financial crisis. The analysis uses the intertemporal model of the current account to gauge the extent of external imbalances before and after the Asian financial crisis, and explores the ability of current account imbalances in predicting the crisis.

The remainder of the paper is organized as follows. Section II provides the theoretical model of the intertemporal approach to the determination of the current account. Section III discusses briefly the panel-based testing procedure, as well as, the data utilized in this study. The empirical results are reported in section IV.

\footnotetext{
${ }^{4}$ The development of the econometric analysis of panel data has received a lot of attention since the mid 1990s. Two excellent surveys on this subject matter are Banerjee (1999) on panel unit roots and cointegration test, and Baltagi and Kao (2000) who extend the discussion further into estimation and inference in the panel cointegration models.
} 
Finally, section V contains some concluding remarks.

\section{Theoretical Model}

We adopt the intertemporal model suggested in Hakkio and Rush (1991) and Husted (1992) to determine the sustainability of the current account in the selected Asian countries. The model starts with the budget constraint of an individual who is able to borrow and lend freely to the rest of the world. Clearly, this model can be extended from an individual to a household or to a country. The current-period budget constraint of this representative household is:

$$
C_{0}=Y_{0}+B_{0}-I_{0}-\left(1+i r_{0}\right) B_{-1}
$$

where $C_{0}$ denotes current consumption; $Y_{0}$ is current output; $I_{0}$ is investment expenditure; $i r_{0}$ is the world interest rate; $B_{0}$ is international borrowing (which could be positive or negative); and $\left(1+i r_{0}\right) B_{-1}$ is the initial debt of the representative household, corresponding to the country's external debt.

Since equation (1) must hold for every time period, the period-by-period budget constraints can be added up to form the economy's intertemporal budget constraint. This constraint can be expressed as:

$$
B_{0}=\sum_{t-1}^{\infty} \delta_{t} T B+\lim _{n \rightarrow \infty} \delta_{n} B_{n}
$$

where $T B_{t}=E X_{t}-M M_{t}=Y_{t}-C_{t}-I_{t}$ represents the trade baląnce in period $t$ (income minus absorption), $E X_{t}=$ exports, $M M_{t}=$ imports, $\delta_{t}=\prod_{s=1} \rho s$ where $\rho_{\mathrm{s}}=$ $1 /\left(1+i_{s}\right)$, and $\delta_{t}$ is the discount factor. The crucial element in equation (2) is the last term $\lim \delta_{n} B_{n}$, where the limit is taken as $n \rightarrow \infty$. When this limit term equals zero, the amount that a country borrows (lends) in international markets is equal the present value of the future trade surpluses (deficits). If $B_{0}$ is positive, then the country is 'bubble-financing' its external debt, and in the case $B_{0}$ is negative and the limit term is non-zero, the country is making Pareto-inferior decisions: welfare could be raised by lending less (Husted, 1992).

Assuming that the world interest rate is stationary with unconditional mean ir, Equation (1) may be expressed as ${ }^{5}$ :

\footnotetext{
${ }^{5}$ See for example, Husted (1992) and Apergis et al. (2000).
} 


$$
Z_{t}+(1+i r) B_{t-1}=E X_{t}+B_{t}
$$

where $Z_{t}=M M_{t}+\left(i r_{t}-i r\right) B_{t-1}$. Solving equation (3) by forward substitution, Hakkio and Rush (1991) and Husted (1992) obtain the following relationship:

$$
M M_{t}+i r_{t} B_{t-1}=E X_{t}+\sum_{j=0}^{\infty} \phi^{j-1}\left[\Delta E X_{t+j}-\Delta Z_{t+j}\right]+\lim _{j \rightarrow \infty} \phi^{t+j} B_{t+j}
$$

where $\phi=1 /(1+r)$ and $\Delta$ denotes the first-difference operator. The left-hand side of (4) represents spending on imports as well as interest payments (receipts) on net foreign debt (assets). Subtracting $E X_{t}$ from both sides of equation (4) and multiplying the result by $(-1)$, then the left-hand side of equation (4) represents the current account of an economy. Further, by assuming the limit term that appears in equation (4) is zero and adding a residual term to equation (4), the following regression model is obtained:

$$
E X_{t}=a+b M M^{*}+\mu_{t}
$$

where $M M^{*}=\left(M M_{t}+i r_{t} B_{t-1}\right)$ measures imports of goods and services plus net unilateral transfers. The necessary condition (weak form) for the economy to satisfy its intertemporal budget constraint is the existence of a stationary error structure, that is, $\mu_{t}$ in equation (5) should be an $I(0)$ process. On the other hand, failure to detect comovements between exports (inflows) and imports (outflows) would indicate the economy is not functioning properly and fails to satisfy its budget constraint, and therefore, is expected to default on its debt (Hakkio and Rush, 1991).

The necessary and sufficient condition (strong form) for the intertemporal budget constraint model is the existence of a vector $(a, b)$ such that the process is stationary and $(a, b)=(0,1)$. In other words, if exports and imports are cointegrated with cointegrating vector $\beta=(1,-1)$, then the economy is said to satisfy its strong form of the intertemporal budget constraint in the long run. Such a relationship would imply that the two series would never drift too far apart. Equation (5) above provides a useful framework for testing the sustainability of current account deficits (or surpluses).

\section{Panel Unit Root and Panel Cointegration Tests}

In this section a brief discussion of the methodology of panel unit root and panel cointegration tests is provided. For a more comprehensive discussion on these 
procedures and their applications, the reader may refer to Baltagi and Kao (2000), Wu et al. (2001), and Azali et al. (2001), among others.

\section{A. Panel Unit Root Test}

Recently, Im, Pesaran and Shin (1997) (hereinafter referred to as IPS) proposed two panel-data unit root tests based on the mean group approach: the LM-bar and t-bar statistics. The t-bar test tends to perform better than the LM-bar as shown by the Monte Carlo experiments in the absence of autocorrelation when $N \rightarrow \infty$ and achieve more accurate size and higher power relative to the Levin and Lin (1993) test, by allowing for a greater degree of heterogeneity. In short, the t-bar statistic is given by

$$
\Gamma_{i}=\frac{\sqrt{N}\left\{\dot{t}_{N T}-E\left(t_{T} \mid \beta_{t}=0\right)\right.}{\sqrt{\operatorname{Var}\left(t_{T} \mid \beta_{i}=0\right)}} \Rightarrow N(0,1), \text { where } \dot{t}_{N T}=\frac{1}{N} \sum_{i=1}^{N} t_{i T}
$$

such that $\dot{t}_{N T}$ is the average of the Augmented Dickey-Fuller (ADF) t-statistics for individual countries. The terms $E\left(t_{T} \mid \beta_{i}=0\right)$ and $\operatorname{Var}\left(t_{T} \mid \beta_{i}=0\right)$ are the common mean and variance of $\mathrm{t}_{\mathrm{iT}}$, where $i=1,2, \ldots, N$, obtained under $\beta_{\mathrm{i}}=0$.

\section{B. Panel Cointegration}

If the relevant variables in the panel are nonstationary, the system can be tested for cointegration. Pedroni $(1997,1999)$ develop a number of statistics based on the residuals of the cointegrating regression. The method allows different individual effects across $N$ or cross-sectional interdependency. In particular, the Pedroni test is based on the null hypothesis of no cointegration versus the alternative hypothesis that suggests the variables form a cointegrating relationship. Assuming a panel of $\mathrm{N}$ countries each with $\mathrm{m}$ regressors $\left(X_{m}\right)$ and $T$ time series observations, in general, the long-run model may take the form

$$
\begin{gathered}
Y_{i, t}=\alpha_{i}+\phi_{i} t+\eta_{1 i} X_{I i, t}+\eta_{2 i} X_{2 i, t}+\ldots+\eta_{M i} X_{M i, t}+\varepsilon_{i, t} \\
\text { for } t=1, \ldots, T ; i=1, \ldots, N ; m=1, \ldots, M
\end{gathered}
$$

Equation (7) implies that all coefficients, and hence the cointegrating vector, vary across countries, thus permitting full heterogeneity $\left(\eta_{i}\right)$, fixed effects $\left(\alpha_{i}\right)$ and individual specific deterministic trends $\left(\phi_{i} t\right)$ across individual members of the 
panel. Based on the cointegrating residuals, $e_{i, t}$, Pedroni $(1997,1999)$ develop seven panel cointegration statistics ${ }^{6}$. Four of these statistics are called panel cointegration statistics (the within-dimension) constructed by summing both the numerator and the denominator terms over the $N$ dimension separately. The other three statistics, called group mean panel cointegration statistics (betweendimension) are constructed by dividing the numerator by the denominator prior to summing over the $N$ dimension. The standardized distributions for all seven Pedroni estimators are given by

$$
\frac{e_{N, T}-\mu \sqrt{N}}{\sqrt{v}} \Rightarrow N(0,1)
$$

where $e_{N, T}$ is the respective panel/group cointegration statistic, and $\mathrm{m}$ and $\mathrm{n}$ are the expected mean and variance of the corresponding statistics, respectively. They are computed by Monte Carlo simulation and are tabulated in Pedroni (1999, Table $\left.2^{7}\right)$.

\section{Estimating the Cointegrating Vectors in Panels}

Once the null hypothesis of no cointegration has been rejected, the coefficients of the long-run relationships can be estimated using the Kao and Chiang (2000) DOLS method. The DOLS procedure involves running the following regression:

$$
R X Y_{i, t}=\alpha_{i}+\beta_{i} R M Y_{i, t}+\sum_{j=-q}^{q} c_{i j} \Delta R M Y_{i, t+j}+\varepsilon_{i t}
$$

where $t=1, \ldots, T$ and $i=1, \ldots, N$. Equation (9) includes the leads and lags of $\Delta \mathrm{RMY}_{\mathrm{it}}$ in the cointegrating regressions in order to produce asymptotically unbiased estimators and to avoid the problem of estimating nuisance parameters. The Monte Carlo simulations presented in Kao and Chiang (2000) have shown that the DOLS estimator outperforms both the Ordinary Least Squares (OLS) and Fully Modified Ordinary Least Squares (FMOLS) estimators for both the homogeneous and heterogeneous panels.

\footnotetext{
${ }^{6}$ For a detailed description of the mathematical formulae for the seven panel cointegration statistics, see Pedroni (1999), Table 1. The asymptotic distribution of the small sample performance for the seven tests in heterogeneous panels is explored and derived by Pedroni (1997). Pedroni also shows that under an appropriate standardization based on the moments of vector of Brownian motion functional, each of these statistics is distributed as an asymptotic standard normal when both the time series (T) and cross sectional dimensions $(\mathrm{N})$ of the panel grow large.
}

${ }^{7}$ The authors are grateful to Pedroni for providing the program to test the relationship. 


\section{Data Description}

In this study, annual frequency data spanning from 1970 to 2000 for all the Asia8 countries are utilized. As mentioned earlier, these Asia- 8 countries are Thailand, Indonesia, Malaysia, the Philippines, Singapore, Taiwan, South Korea, and Japan. Most of the Asia- 8 economies were affected by the recent financial crisis. They suffered noticeable currency depreciation following the outbreak of the crisis in July 1997 but the extent of the slide in their currencies differ from one country to another ${ }^{8}$. In order to examine the effect of the currency crisis on the Asia- 8 current accounts, we consider two time periods. The first period starts in 1970 and ends in 1997. It coincides with the rapid-growth period of the Asia- 8 countries. The second period expands the sample by including the crisis and subsequent years (19702000). During the latter years of this period many of these countries enjoyed current account surpluses?.

All of the data are gathered from various issues of International Financial Statistics published by International Monetary Fund (IMF). Real exports (RXY) include exports of goods and services, while real imports (RMY) includes imports of goods and services plus net transfer payments and net interest payments (Husted, 1992). Both exports and imports are measured in real terms as a percentage of real GDP. The consumer price index (CPI) is used as a proxy for national price and for consistency in the panel; all variables are expressed in US dollars.

\section{Empirical Results}

\section{A. IPS Unit Root Test}

To identify possible unit roots, the IPS test is performed for levels and first differences. The degree of augmentation for the unit root test is based on the procedure recommended by Campbell and Perron (1991). Overwhelmingly, the test results reported in Table 1 suggest that there exists a panel unit root in all variables

\footnotetext{
${ }^{8}$ Following the Asian financial crisis, the value of the Indonesia rupiah depreciated to a level one-sixth of the pre-crisis value; the currencies of other ASEAN countries and the Korean won depreciated to a level half of the pre-crisis value.

${ }^{9}$ Preliminary test results reveal that, based on the Johansen and Juselius multivariate cointegration approach, the finding of current account stationarity of the individual Asia- 8 countries differs across these two time periods.
} 
Table 1. IPS Panel Unit Root Test ${ }^{\mathrm{a}}$

\begin{tabular}{|c|c|c|}
\hline \multirow{2}{*}{ Variables } & \multicolumn{2}{|c|}{ IPS $\dot{t}$ statistics } \\
\hline & Without trend & With trend \\
\hline & \multicolumn{2}{|c|}{ Level } \\
\hline \multicolumn{3}{|c|}{ A: Sample Period 1970-1997 } \\
\hline RXY & -0.802 & -0.250 \\
\hline RMY & -0.917 & -1.053 \\
\hline \multicolumn{3}{|c|}{ B: Sample Period 1970-2000 } \\
\hline RXY & -0.298 & -1.567 \\
\hline RMY & -0.619 & -1.600 \\
\hline \multicolumn{3}{|c|}{ First Difference } \\
\hline \multicolumn{3}{|c|}{ C: Sample Period 1970-1997 } \\
\hline$\Delta \mathrm{RXY}$ & $-6.951^{*}$ & $-5.967^{*}$ \\
\hline$\Delta \mathrm{RMY}$ & $-6.651^{*}$ & $-5.416^{*}$ \\
\hline \multicolumn{3}{|c|}{ D: Sample Period 1970-2000 } \\
\hline$\Delta \mathrm{RXY}$ & $-10.814^{*}$ & $-10.153 *$ \\
\hline$\Delta \mathrm{RMY}$ & $-10.371^{*}$ & $-8.861^{*}$ \\
\hline
\end{tabular}

aPS indicates the Im et al. (1997) test. The critical values are taken from IPS (1997), Table 4. RXY and RMY are defined in the main text of the paper. The estimates of the $\dot{t}$ statistics are based on the standard ADF statistics. (*) indicates statistical significance at the 5 per cent level and $\Delta$ denotes the first difference operator.

under investigation for the two sample periods ${ }^{10}$.

\section{B. Pedroni Test}

Having determined the presence of a unit root in the variables, we proceed to the panel cointegration tests. The cointegration results in Table 2 provide strong evidence against the null of no cointegration for all seven statistics provided by Pedroni (1999). These empirical results hold for both sample periods. This implies that, taken as a group, the current account imbalances in the pre-crisis period and the period including the crisis (1970-2000) are indeed on a sustainable path. More importantly, the results indicate the benefits of using pooled panel data that allow us to exploit the additional variability inherent in cross-sectional information. Despite the disparities in the individual countries, we find that exports and imports

\footnotetext{
${ }^{10}$ The application of the IPS panel unit root test for the current account balance (defined as the difference between exports and imports) shows that this variable is stationary in both sample periods, thus implying sustainability (the results are not reported but are available upon request from the authors). However, such a test is based on the untested assumption that the coefficient $\beta$ is equal to one. This shortcoming is avoided by, first, testing for cointegration between exports and imports, and then testing the restriction that the parameter $\beta$ is statistically not different from one (see Tables 2 and 3 below).
} 
Table 2. Pedroni Panel Cointegration Test ${ }^{\mathrm{a}}$

\begin{tabular}{ll}
\hline \multicolumn{1}{c}{$T^{c}$ Aest Statistics $^{\mathrm{b}}$} \\
\hline \multicolumn{1}{c}{ A: Sample Period 1970-1997 } \\
\hline Panel cointegration statistics (within-dimension) \\
\hline Panel v-statistic & 5.42075 \\
Panel $\rho$-statistic & -4.97616 \\
Panel pp-statistic & -4.91538 \\
Panel adf -statistic & -4.80819 \\
\hline Group mean panel cointegration statistics (between-dimension) & \\
\hline Group $\rho$-statistic & -5.07687 \\
Group pp-statistic & -6.82520 \\
Group adf-statistic & -6.70432 \\
\hline B: Sample Period 1970-2000 & \\
\hline Panel cointegration statistics (within-dimension) & \\
\hline Panel v-statistic & 4.42214 \\
Panel $\rho$-statistic & -2.28812 \\
Panel pp-statistic & -1.68924 \\
Panel $a d f$-statistic & -3.16640 \\
\hline Group mean panel cointegration statistics (between-dimension) & \\
\hline Group $\rho$-statistic & -2.50759 \\
Group pp-statistic & -2.86638 \\
Group $a d f$-statistic & -2.86638 \\
\hline
\end{tabular}

${ }^{a}$ The number of lag truncations used in the calculation of the seven Pedroni statistics is 3 . The 5 per cent critical value is -1.645 since the residual-based test is a one-tail test. Hence, large negative values (left tail) imply the rejection of the null hypothesis of no cointegration. One exception is the panel v-statistics that diverge to positive infinity (right tail), thus requiring large positive values (larger than 1.645) to reject the null of no cointegration. The critical values for the mean and variance of each statistic were obtained from Pedroni (1999), Table 2. All the estimations and the calculation of the panel cointegration statistics were carried out in RATS 4.2 using the algorithm kindly provided by Pedroni.

${ }^{\mathrm{b}}$ Panel $\rho$ is a non-parametric variance ratio statistic; panel $r$ and the panel $p p$ are analogous to the nonparametric Phillips-Perron $\rho$ and t-statistics, respectively; panel adf is the parametric statistic based on the Augmented Dickey-Fuller ADF statistic; group $\rho$ and group pp are the non-parametric Phillips-Perron $\rho$ and t-statistics, and group adf is the standard parametric ADF statistic.

of the Asia- 8 are cointegrated. To check against the possibility that these results are due to the inclusion of Taiwan, Singapore and Japan (the non-affected by the Asian crisis countries), we compute the pooled statistics after omitting these countries. The results (not shown here) appear to be unaffected by the exclusion of these countries.

\section{The Kao and Chiang (2000) DOLS approach}

Given that exports and imports are cointegrated in both sample periods, we then estimate equation (9) using the method of DOLS as proposed by Kao and Chiang 
(2000). We also test whether the cointegration coefficient $\beta$ is significantly different from 0 and insignificantly different from 1 .

The estimated long-run relationships using the DOLS procedure are reported in Table 3. In Model 1 (pre-crisis), the estimated $\beta$ is 0.697 , which is not close to unity. Both the null hypotheses of $\beta=0$ and $\beta=1$ are easily rejected for Model 1. As such, the empirical results suggest that exports (RXY) and imports (RMY) are cointegrated with the cointegrating coefficient less than 1, implying that the current account was not on the sustainable path (weak form of sustainability) prior to the crisis. Also, this finding supports the proposition that the current account was possibly a major determinant of the Asian financial crisis. The model yields an adjusted $R^{2}$ of 0.738 , suggesting that 74 per cent of the variation in RXY can be explained by the explanatory variable RMY. However, caution should be taken when interpreting the goodness of fit in panel data. In other words, the conventional stability test for univariate series cannot be directly extended to panel data. The asymptotic properties of the stability tests in the environment of panel data are yet to be proven in the literature.

For Model 2 (including the post-crisis period), the estimated $\beta$ is 0.903 , i.e., much bigger than that obtained from Model 1 . The null hypothesis $\beta=1$ is not rejected while the hypothesis $\beta=0$ is easily rejected at the conventional significance levels. Indeed, we find that the current account imbalances are on a sustainable (strong form of sustainability) path if the post-crisis period is included in our sample. Thus, the measures taken by the authorities, as well as, the adjustments in macroeconomic variables (for example, interest rates, exchange rates, etc) during the crisis brought the current account imbalances back to a sustainable path and none of the countries in the panel of the selected East Asia economies tended to default on its international debt. The adjusted $R^{2}$ is 0.792 .

Table 3. DOLS estimation for panel cointegration ${ }^{\mathrm{a}}$

\begin{tabular}{lcc}
\hline \multicolumn{1}{c}{ Parameters } & Model $1^{\mathrm{b}}$ & Model $2^{\mathrm{c}}$ \\
\hline$\beta$ & 0.697 & 0.903 \\
$\mathrm{H}_{0}: \beta=1$ & $22.633^{\mathrm{d}}$ & 0.293 \\
$\mathrm{H}_{0}: \beta=0$ & $121.416^{\mathrm{d}}$ & $25.457^{\mathrm{d}}$ \\
Adjusted $\mathrm{R}^{2}$ & 0.738 & 0.792 \\
\hline
\end{tabular}

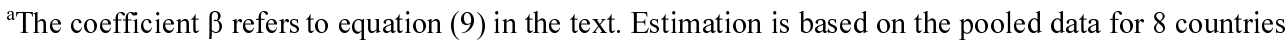
with four lags and two leads of first differenced explanatory variables.

${ }^{b}$ Model 1 refers to the sample period 1970-1997.

${ }^{\mathrm{c}}$ Model 2 refers to the sample period 1970-2000.

${ }^{\mathrm{d}}$ Denotes statistical significance at the 1 per cent level. 


\section{Conclusions}

The recent Asian financial crisis has highlighted the need for emerging economies to maintain sustainable external imbalances. The experience of several of the Asian countries suggests that unsustainable current account disequilibria can cause large swings in exchange rates. The primary purpose of this study is to investigate empirically the sustainability of the current account in the Asian countries. In contrast to most previous empirical analyses, the present study tests for the sustainability of the current account as predicted by the intertemporal model using panel data. The advantage of the panel data approach is that it can combine information from time series and cross section data. It is now well known that the panel cointegration and DOLS methods overcome the power deficiencies of tests based on pure time series data.

The results of the analysis lead to the several interesting conclusions. First, in the pre-crisis period, the evidence suggests that the sufficient condition for the intertemporal model is violated. It is known that for the crisis-affected countries (Thailand, Indonesia, South Korea, Malaysia and the Philippines) the external balances reached a crisis level. Thus, economic policies put in place prior to the crisis (including the peg exchange rate system) contributed to the violation of the expected intertemporal constraint. An important lesson that can be drawn from this finding is that lack of a policy action to correct the widening of current account deficits by the relevant authorities may be conducive to a financial crisis.

Second, the current account imbalances of the Asia- 8 countries seem to be on a sustainable path in the post-crisis era. There is no indication that these Asia-8 countries will tend to default on their international debt. We also observe that the current account of the crisis-affected countries moved from large deficits to surpluses over a relatively short time period following large currency depreciations, as well as, adjustments in other macroeconomic variables of the East-Asia countries. Among the five crisis-affected countries, Korea and Malaysia are on a fast recovery track, while the rest are still on the recovery path. This result is consistent with Hossain (1999) who finds a meaningful relationship between changes in real exchange rates and the current account in both the US and Japan. Similarly, Baharumshah (2001) finds that trade balances are affected by exchange rates as well as other macroeconomic variables in Malaysia and Thailand.

Finally, and perhaps more importantly, the finding of the violation of the sufficient condition for sustainability implies that, as the experience of the Asian 
crisis indicates, a large and persistent current account deficit may trigger a financial crisis. In other words, the current account path may be used as an indicator to predict financial crises. Therefore, the policy implication arising from this analysis is that the Asia- 8 countries should have implemented policy measures before 1997 to correct their unsustainable external imbalances. A similar assessment on the this issue has also been offered by Glick et al. (1995), who argue that most Asian currencies pegged their exchange rate (to the US dollar) to prevent the necessary adjustments to external shocks.

Received 27 February 2004, Accepted 16 December, 2004

\section{References}

Azali, M, Habibullah, M. S. and Baharumshah, A.Z. (2001) Does PPP hold between Asian and Japanese Economies? Evidence Using Panel Unit Root and Panel Cointegration, Japan and World Economy, 13, 35-50.

Adedeji, O.S. (2001) The Size and Sustainability of Nigerian Current Account Deficits, IMF Working Paper No. 87

Apergis, N., Katrakilidis, K. P. and Tabakis, N. M. (2000) Current Account Deficit Sustainability, Applied Economics Letters, 7, 599-603.

Baharumshah, A.Z. (2001) The Effect of Exchange Rate on Bilateral Trade Balance: New Evidence from Malaysia and Thailand, Asian Economic Journal, 15, 291-312.

Baltagi, B. and Kao, C. (2000) Nonstationary Panels, Cointegration in Panels and Dynamic Panels: A Survey, in Baltagi, Badi, Fomby, Thomas B. and Hill, R. Carter (ed.), Advances in Econometrics : Nonstationary Panels, Cointegration in Panels and Dynamic Panels, Vol: 15, 7-51.

Banerjee, A. (1999) Panel Data Unit Roots and Cointegration: An Overview, Oxford Bulletin of Economics and Statistics, 61, 607-629.

Cashin, P. and McDermott, C. J. (1998) Are Australia's Current Account Deficits Excessive?, The Economic Record, 74, 346-361.

Campbell, J.Y. and Perron, P., (1991) Pitfalls and Opportunities: What Macroeconomists Should Know About Unit Roots, in Olivier J. Blanchard and Stanley Fischer (ed.), National Bureau of Economic Research Macroeconomics Annual, MIT Press, Cambridge, 144-201.

Engle, R.F. and Granger, C.W.J. (1987) Cointegration and Error Correction: Representation, Estimation and Testing, Econometrica, 55, 251-276.

Fountas, S. and Wu, J-L. (1999) Are the U.S. Current Account Deficits Really Sustainable?, International Economic Journal, 13, 51-58.

Glick, R., Hutchison, M. and Moreno, R (1995). Is Pegging Exchange Rate A cure for Inflation? East Asian Experience, Pacific Basin Working Paper Series, No. PB95-08, 
Center for Pacific Basin Monetary and Economic Studies, Federal Reserve Bank of San Francisco.

Hakkio, C. S. and Rush, M. (1991) Is the Budget Deficit 'Too Large'?, Economic Inquiry, 29, 429-425.

Holman, J A. (2001) Is the Large US Current Account Deficit Sustainable?, Economic Review, Federal Reserve Bank of Kansas City, First Quarter, 5-23.

Hossain, F. (1999) Transitory and Permanent Disturbances and the Current Account: An Empirical Analysis in the Intertemporal Framework, Applied Economics, 31, 965974.

Husted, S. (1992) The Emerging U.S. Current Account Deficit in the 1980s: A Cointegration Analysis, The Review of Economics and Statistics, 74, 159-166.

Im, K.S., Pesaran, M.H. and Shin, Y. (1997) Testing for Unit Roots in Heterogeneous Panels, Working Paper, University of Cambridge.

Irandoust, M. and Boo S. (2000) The Behavior of the Current Account in Response to Unobservable and Observable Shocks, International Economic Journal, 14, 41-57.

Johansen, S. and Juselius, K. (1990) Maximum Likelihood Estimated and Inference on Cointegration with Application to the Demand for Money, Oxford Bulletin of Economics and Statistics, 52, 169-210.

Kao, C. and Chiang, M.-H. (2000) On the Estimation and Inference of a Cointegrated Regression in Panel Data, in Baltagi, Badi, Fomby, Thomas B. and Hill, R. Carter (ed.), Advances in Econometrics: Nonstationary Panels, Cointegration in Panels and Dynamic Panels, Vol: 15, 179-222.

Levin, A. and Lin, C.F. (1993) Unit Root Tests in Panel Data: New Results, University of California at San Diego (UCSD) Discussion Paper No. 56.

Mann, C., (2002) Perspectives on the US current account deficit and sustainability, Journal of Economic Perspectives, 16, 131-152.

Milesi-Ferretti, G. M. and Razin, A. (1996) Current Account Sustainability: Selected East Asian and Latin American Experiences, National Bureau of Economic Research (NBER), Working Paper No. 5791.

Obstfeld, M. and Rogoff, K. (1996) Foundations of International Macroeconomics, The MIT Press, Massachusetts.

Otto, G. (1992) Testing a Present Value Model of the Current Account: Evidence from US and Canadian Time Series, Journal of International Money and Finance, 11, 414430.

Pedroni, P. (1997) Panel Cointegration, Asymptotic and Finite Sample Properties of Pooled Time Series Tests with an Application to the PPP Hypothesis: New Results, Indiana University Working Paper in Economics.

Pedroni, P. (1999) Critical Values for Cointegration Tests in Heterogeneous Panels with Multiple Regressors, Oxford Bulletin of Economics and Statistics, 61, 653-670.

Schwartz, A. (2003) Interpreting the US current account deficit, manuscript prepared for the Shadow, Open Market Committee meeting, November 9-10.

Shibata, A. and Shintani, M. (1998) Capital Mobility in the World Economy: An Alterna- 
tive Test, Journal of International Money and Finance, 17, 714-756.

Shiller, R.J. and Perron, P. (1985) Testing the Random Walk Hypothesis: Power versus Frequency of Observation, Economics Letters, 39, 381-386.

Wickens M.R. and Uctum, M. (1993) The Sustainability of Current Account Deficits: A Test of the U.S. Intertemporal Budget Constraint, Journal of Economic Dynamics and Control, 17, 423-441

Wu, J-L. (2000) Mean Reversion of the Current Account: Evidence from Panel Data UnitRoot Test, Economics Letters, 66, 215-222.

Wu, J-L., Chen, S-L. and Lee H-Y. (2001) Are Current Account Deficits Sustainable? Evidence from Panel Cointegration, Economics Letters, 72, 219-224.

Yan, H-D. (1999) Intertemporal Current Account Balance and the East Asian Currency Crisis, International Advances in Economic Research, 5, 277-288. 